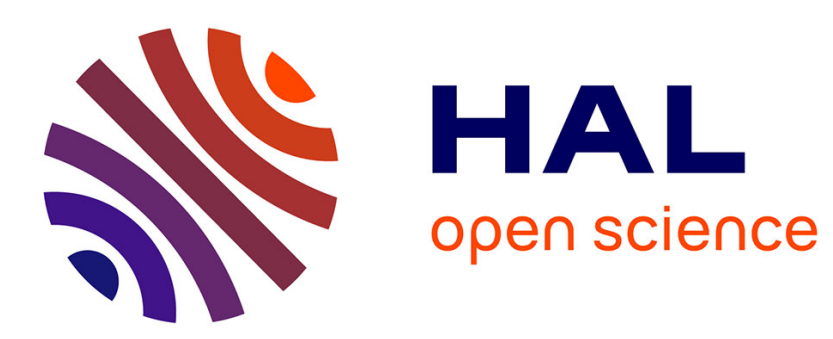

\title{
Effect of organic cryosolvents on actin structures and actin/[MATH]-actinin binding geometries
}

\author{
E. Pajot-Augy, M. Axelos
}

\section{To cite this version:}

E. Pajot-Augy, M. Axelos. Effect of organic cryosolvents on actin structures and actin/[MATH]actinin binding geometries. Journal de Physique IV Proceedings, 1993, 03 (C8), pp.C8-241-C8-244. 10.1051/jp4:1993846 . jpa-00252277

\section{HAL Id: jpa-00252277 https://hal.science/jpa-00252277}

Submitted on 1 Jan 1993

HAL is a multi-disciplinary open access archive for the deposit and dissemination of scientific research documents, whether they are published or not. The documents may come from teaching and research institutions in France or abroad, or from public or private research centers.
L'archive ouverte pluridisciplinaire HAL, est destinée au dépôt et à la diffusion de documents scientifiques de niveau recherche, publiés ou non, émanant des établissements d'enseignement et de recherche français ou étrangers, des laboratoires publics ou privés. 


\title{
Effect of organic cryosolvents on actin structures and actin/ $\alpha$-actinin binding geometries
}

\author{
E. PAJOT-AUGY(1) and M.A.V. AXELOS*
}

Unité de Recherche en Développement Concerté, INRA-INSERM (U. 310), Institut de Biologie PhysicoChimique, 13 rue Pierre et Marie Curie, 75005 Paris, France

* INRA, Laboratoire de Physicochimie des Macromolécules, BP. 527, 44026 Nantes cedex 03, France

\begin{abstract}
Cryopreservation procedures of living cells involve the use of organic solvents against freezing damage. An efficient cryoprotection might be achieved by obtaining a cytoplasmic gel able to reduce water flux and avoid crystallization. Small angle X-ray scattering experiments were performed at LURE (Orsay, France) to investigate the effects of $1,2-$ propanediol and glycerol on the structure of actin, a major cytoplasmic protein, and on the binding geometries of actin to $\alpha$ actinin, an interconnecting protein. In the presence of 1,2-propanediol, monomeric G-actin exhibits oligomerization into short rod-like structures very close to that of salt-polymerized actin filaments (F-actin). In the presence of $\alpha$-actinin, F-actin filaments aggregate into thick and tight bundles. The scattering pattern in the presence of propanediol suggests a "ladder-like" structure with a tilt angle of the $\alpha$-actinin molecule relative to F-actin filaments. This angle is even larger with glycerol. The resulting loose structures favor the formation of a microporous network. All these results support previous electron microscopy observations and the structural mechanisms deduced from rheological measurements.
\end{abstract}

\section{Introduction}

Organic cryosolvents action upon actin-linked cytoskeleton may be critical for cryoprotection. Trapping water within the pores of a cytoplasmic gel could be a means to reduce water flux, avoid its crystallization, and even obtain vitrification. 1,2-propanediol induces shortening and bundling F-actin filaments [1-3]. Actin protomers within microfilaments undergo a conformational change which yields a conformation closer to that of monomeric actin [3]. Moreover, F-actin interaction with a number of actinbinding proteins is modified in the presence of 1,2-propanediol. $\alpha$-actinin binding to F-actin is enhanced $[3,4]$. Thick bundles of F-actin/ $\alpha$-actinin determine a very coarse network without 1,2-propanediol, whereas its presence induces the formation of a microporous homogeneous network [3-6] able to vitrify by rapid cooling [5].

Small-angle $X$-ray scattering experiments were undertaken to study cryosolvents influence upon monomeric actin, and to examine any modification in the geometry of $\alpha$-actinin binding to F-actin in the presence of cryosolvents which could account for the global structural changes observed.

\section{Materials and methods}

Actin and $\alpha$-actinin were prepared as described elsewhere $[4,7,8,9]$. Actin concentrations were $2 \mathrm{mg} / \mathrm{ml}$ in the absence of polymerizing salts, $1 \mathrm{mg} / \mathrm{ml}$ for F-actin polymerized with $40 \mathrm{mM} \mathrm{KCl}$ and $1 \mathrm{mM}$ $\mathrm{MgCl}_{2}$, and $1 \mathrm{mg} / \mathrm{ml}$ in systems with $\alpha$-actinin $0.2 \mathrm{mg} / \mathrm{ml}$. 1,2-Propanediol and glycerol concentrations were $15 \%(\mathrm{v} / \mathrm{v})$ and $10 \%(\mathrm{v} / \mathrm{v})$, respectively. All measurements were conducted at $4^{\circ} \mathrm{C}$, where $\alpha$ actinin/actin interaction is maximum [10,11]. For experiments on F-actin or actin/ $\alpha$-actinin mixtures, samples were allowed to polymerize for 2 hours at $4^{\circ} \mathrm{C}$ prior to scattering. Small-angle scattering data were collected on beamline D24 on the storage ring DCI at LURE (Orsay), at $\lambda=1.608 \AA[12,13]$.

(1) Present address: INRA, Laboratoire de Biologie Cellulaire et Molêculaire, Unité d'Ingénierie des Protéines, Domaine de Vilvert, 78352 Jouy en Josas cedex, France 


\section{Results and discussion}

Non-polymerizing ionic conditions [14]

Log-log plots of SAXS patterns (Fig. 1) exhibit a linear section for G-actin with propanediol in the range $0.0045 \AA^{-1}<s<0.009 \AA^{-1}$ with a slope of -1.3 as in F-actin, which seems to indicate that propanediol initiates the formation of elongated structures. The curves for G-actin alone and in propanediol intersect at an isosbestic point around $0.011 \AA$, as do $G$-actin and $F$-actin [15], another indication of actin association similar to that in F-actin.

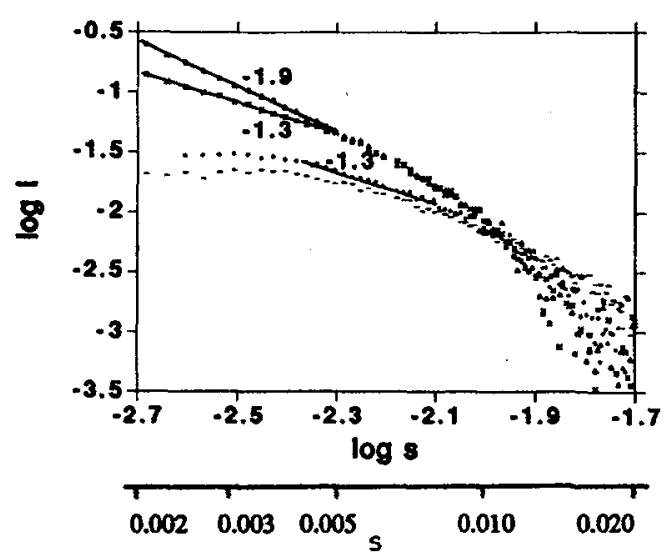

Fig. 1 : Scatttering patterns from G-actin solutions in buffer alone (-.-) or with propanediol $15 \%$ (....), compared to Factin solution without cryosolvent $(x \times x)$ or with propanediol 15\% $(\Delta \Delta \Delta)$.

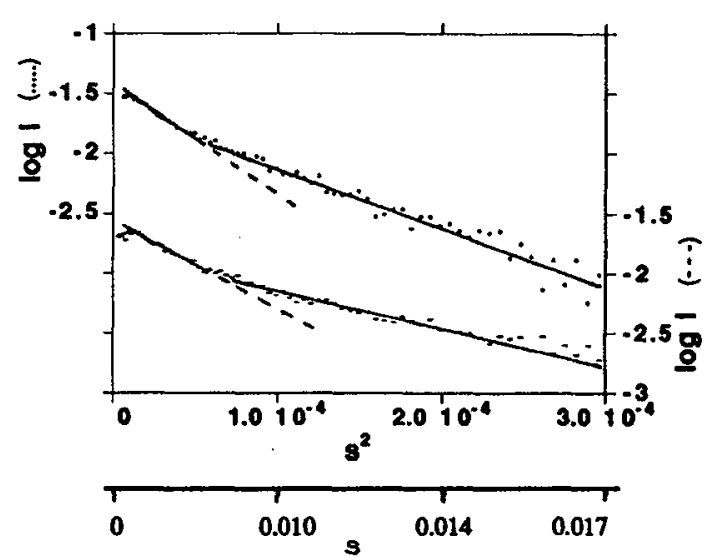

Fig. 2 : Guinier plots of the scattering pattems from G-actin solutions in buffer alone (-- ) or with propanediol $15 \%$ (...). The curve relative to buffer alone (- .-) is shifted one unit downwards in $\log I$ for purpose of readability.

Guinier plots from G-actin in solution with or without propanediol (Fig. 2) are bi-modal, which gives evidence of two scattering species [16], with radii of gyration of $35 \AA \pm 1$ (49\% relative amount) and $23 \AA \pm 1(51 \%)$ in buffer, $40 \AA \pm 0.5$ (45\% relative amount) and $29 \AA \pm 1(55 \%)$ in propanediol. SAXS patterns from G-actin with glycerol or the mixture propanediol/glycerol (not shown) are similar to that in buffer, with radii of gyration of $37 \AA \pm 0.5$ and $23 \AA \pm 1$. The radius of gyration of $23 \AA \pm 1$ found in all solutions studied devoid of propanediol is in excellent agreement with the literature [15, 17-19]. The radii of gyration of $35 \AA$ and $37 \AA$ found in G-actin in buffer, glycerol, or glycerol/propanediol indicate aggregation, may be due to the lack of a gel filtration step immediately prior to the measurements, consistent with formation of actin dimers or oligomers in an end-to-end arrangement [20]. With propanediol, the monomeric radius of gyration of $23 \AA$ is no longer observed : the monomer is no longer the elementary subunit. The values of $29 \AA$ and $40 \AA$ may result from the formation of side-to-side dimers subunits which then associate end-to-end, giving rise to linear but limited structures [20]. Propanediol is a nucleating agent for $\mathrm{G}$-actin, mimicking the early steps of salt-induced polymerization, leading to the formation of short rod-like oligomers. Glycerol and propanediol/glycerol mixture yield no change, suggesting a specific interaction of propanediol with monomeric actin, prevented by the presence of glycerol as a co-solvent.

Since actin polymerization with salts requires a conformational change of monomeric actin, 
propanediol effect on $\mathrm{G}$-actin could also be ascribed to a conformational modification of monomeric actin, possibly due to perturbation of actin hydration shell by preferential exclusion of propanediol [21]. Further addition of salts to the oligomers formed with propanediol could stabilize and elongate the structures to obtain the same final state as by direct salt-polymerization in the presence of propanediol.

\section{F-actin/ $\alpha$-actinin binding}

The small s - range of log-log plots of SAXS patterns can be linearly fitted with slopes of -0.4 for F-actin/ $\alpha$-actinin, -0.8 with propanediol, -1.1 with glycerol or the mixture propanediol/glycerol (Fig. 3). A semi-logarithmic representation of sI versus $s^{2}$ (Fig. 4) exhibits local maxima at $s_{\max }$ leading to values of $1 / \mathrm{s}_{\max }$ of $164 \AA, 222 \AA$ and $208 \AA$ with propanediol, glycerol, and propanediol/glycerol mixture respectively, corresponding to the occurrence of characteristic distances within these systems. For $F$-actin/ $\alpha$-actinin in buffer alone, no such maximum arises over the whole s-range.

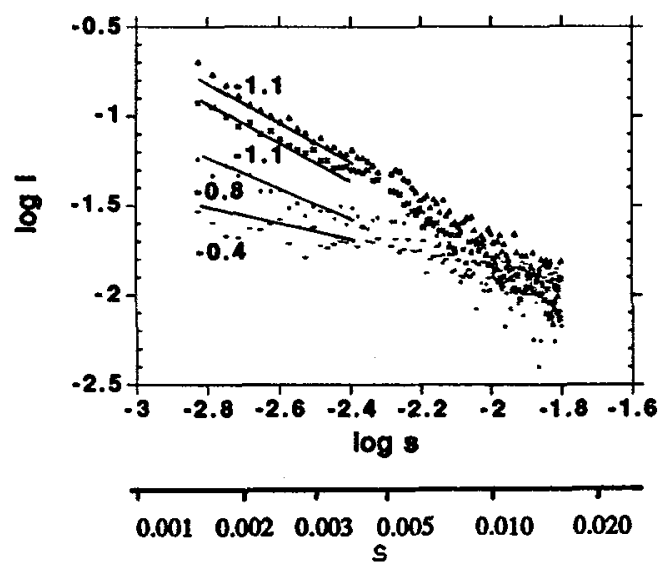

Fig. 3 : Scattering patterns from F-actin/ $\alpha$-actinin solutions in buffer alone (--), propanediol 15\% (....), glycerol $10 \%$ $(\mathrm{x} \times \mathrm{x})$, and propanediol $15 \%+$ glycerol $10 \%(\Delta \Delta \Delta)$.

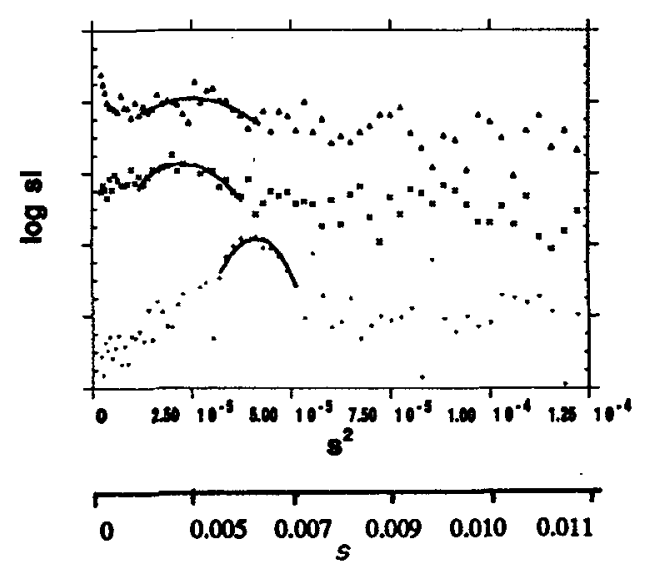

Fig. 4 : Semi-logarithmic plot of sI versus $s^{2}$ for F-actin/ $\alpha$-actinin solutions in propanediol $15 \%$ (....). glycerol $10 \%(x \times x)$, and propanediol $15 \% /+$ glycerol $10 \%(\Delta \Delta \Delta)$. Curves are shifted vertically one relative to the other. Full scale along the $Y$-axis is one logarithmic unit.

$\alpha$-Actinin is a dumbbell-shaped homodimer (30- to $40-\AA$ wide by $348 \AA$ long) $[22,23]$, binding to $F$-actin filaments with each end, forming bundles or networks [24]. Within tight bundles, $\alpha$-actinin molecules are oriented parallel to the F-actin filaments. Lowering $\alpha$-actinin/actin molar ratio induces loose bundles, with $\alpha$-actinin molecules switching to a near-perpendicular orientation relative to filaments (ladder-like structures), with obliquely-oriented intermediates (Fig. 5). In this study, $\alpha$-actinin/actin molar ratio value of $1 / 24$ favors tight bundles with no spacing in the absence of cryosolvents.

The characteristic distances appearing in the presence of cryosolvents suggest a modification in F-actin/ $\alpha$-actinin binding geometry:. The angular tilt of $\alpha$-actinin "rungs" relative to filaments in $10 \%$ glycerol $\left(\theta=38^{\circ}\right)$ is slightly higher than in $15 \%$ propanediol $\left(\theta=27^{\circ}\right)$. The results achieved in $10 \%$ glycerol $+15 \%$ propanediol $\left(\theta=35^{\circ}\right)$ tend to show that glycerol effect is predominant. 

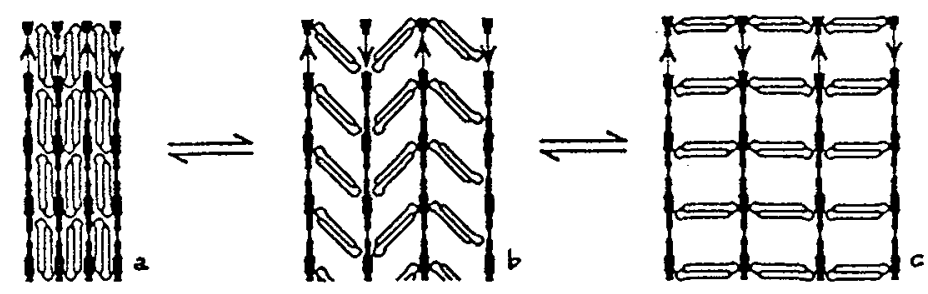

Fig. 5 : Schematic model of F-actin ( - )/ $\alpha$-actinin $(\Longrightarrow$ ) interaction in bundles or networks. (a) Tight bundles, (c) Loce bundles, (b) Intermediate configurations (from [24] with permission)

The slight slopes of logI versus logs with either solvent agree with the presence of such intersticial space in F-actin/ $\alpha$-actinin assemblies. In propanediol, a slope of -0.8 indicates rather short and loose structures in agreement with rheological experiments [6]. In glycerol, associations seem more elongated, with a slope of -1.1. Glycerol does not shorten actin filaments [1], nor promote bundle formation of F-actin alone [14], neither $\alpha$-actinin binding [25] - it rather stabilizes native proteins [26, 27]. Few parallel associations of F-actin interconnected by $\alpha$-actinin may thus form, and they likely involve only two filaments. The observed slope of -1.1 is in agreement with these observations, even if associations are looser than in propanediol $\left(\theta=38^{\circ}\right)$. With both solvents present, a slope of -1.1 suggests loose elongated objects, as with glycerol alone, which has a predominant effect. In buffer, no elongated structures may be inferred whatsoever, since thick F-actin/ $\alpha$-actinin bundles involving many filaments occur $[3,5]$.

Propanediol thus modify $\alpha$-actinin/actin binding by increasing its efficiency, favoring network formation, but also at a geometrical level, loosening the remaining bundles. The whole process favors formation of a water-trapping gel able to vitrify at low temperature.

\section{References}

[1] VINCENT, C, et al., Cryo-Let. 8 (1987) 356

[2] VINCENT, C, et al., Cryobiology 27 (1990) 9

[3] NGUYEN, E, University Thesis, Paris VII (1991)

[4] NGUYEN, E, et al., C. R. Acad. Sci. Paris 307 (1988) 93

[5] PRULIÈRE, G, DOUZOU, P, Biophys. Chem. 34 (1989) 311

[6] PAJOT-AUGY, E, AXELOS, MAV, Cryobiology 29 (1992) 563

[7] SPUDICH, JA, WATT, S, J. Biol. Chem. 246 (1971) 4866

[8] MACLEAN-FLETCHER, S, POLLARD, PD, Biochem. Biophys. Res. Com. 96 (1980) 18

[9] FERAMISCO, JR, BURRIDGE, K, J. Biol. Chem. 255 (1980) 1194

[10] HOLMES, GR, et al., Biochim. Biophys. Acta 253 (1971) 240

(11] JOCKUSCH, BM, ISENBERG, G, Proc. Nall. Acad. Sci. USA 78 (1981) 3005

[12] DEPAUTEX, C, et al., LURE Annual Report, Paris (1987)

[13] BOULIN C, et al., Nucl. Instr. and Meth. A249 (1986) 399

[14] PAJOT-AUGY, E, AXELOS, MAV, Eur. Biophys. J. 21 (1992) 179

[15] MATSUDAIRA, P, et al., Proc. Nasl. Acad. Sci. USA 84 (1987) 3151

[16] GUINIER, A, FOURNET, G, Wiley, New York, Chap 2 and 4 (1955)

[17] PATKOWSKI, A, et al., Biopolymers 30 (1990) 1281

[18] SAYERS, Z, et al., Eur. Biophys. J. 13 (1985) 99

[19] SUCK, D, et al., Proc. Natl. Acad. Sci. USA 78 (1981) 4319

[20] GODDETTE, DW, et al., J. Biol. Chem. 261 (1986) 2605

[21] ARAKAWA, T, et al., Cryobiology 27 (1990) 401

[22] BLANCHARD, A, et al., J. Muscle Res. Cell Motil. 10 (1989) 280

[23] PODBUBNAYA, ZA, et al., J. Mol. Biol. 92 (1975) 357

[24] MEYER, RK, AEBI, U, J. Cell Biol. 110 (1990) 2013

[25] AXELOS, MAV, PAJOT-AUGY, E, In : Theoretical and Applied Rheology, Moldenaers \& Keunings, eds., Elsevier Science Publishers B.V. (1992) 729

[26] GEKKO, K, TIMASHEFF, SN, Biochem. 20 (1981) 4667

[27] GEKKO, K, TIMASHEFF, SN, Biochem. 20 (1981) 4677 